\title{
PASSAGES
}

Philippine Journal Of Otolaryngology-Head And Neck Surgery

\section{Jomar S. Tinaza, MD (1969-2015)}

Emmanuel Tadeus S. Cruz, MD

Karen Adiel D. Rances, MD

\section{"Every morning you have two choices: Continue to sleep with your dreams or wake up and chase them." - J.S. Tinaza}

\begin{abstract}
Dr. Tinaza may not have been Shakespeare, Poe or Frost but he was known for his meaningful verses which he posted on viber, mundane and profound thoughts about life and recent photos he captured in his timeline.

Dr. Jomar S. Tinaza obtained his Doctor of Medicine degree from the De La Salle University College of Medicine in 1995. He joined the Quezon City General Hospital residency training program with Dr. Carmina G. Galang in January 2000. In January 2003, the Philippine Board of Otolaryngology-Headand NeckSurgeryaccredited the training program. Dr. Galang graduated in 2004 while Jomar opted to extend his training for two years to complete the four years needed to become board-eligible. Hence, Jomar was the first alumnus of the QCGH ENT Department. He passed the
\end{abstract}

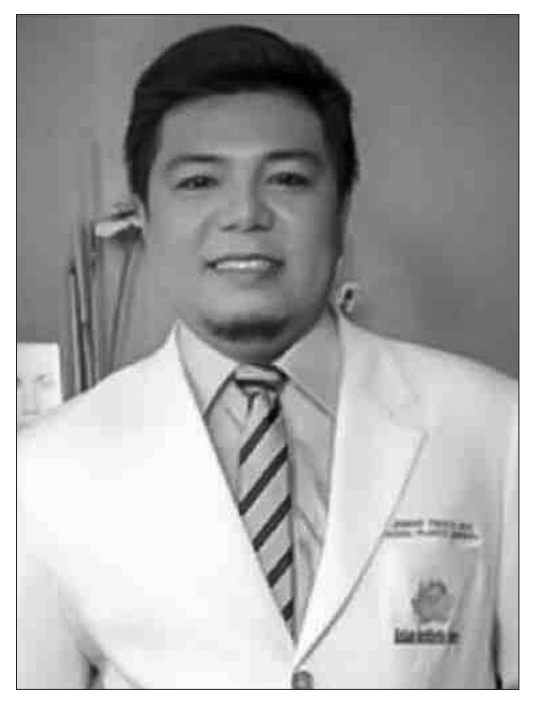
descriptive paper on a case series of rhinoplasty in cleft noses; and he helped amputate an Abbe flap on a clinical patient with lip cancer, a week before he left. He was invited to lecture in a postgraduate course at St. Luke's Medical Center after the PSOHNS annual convention and he subsequently gave an inspirational talk where he emphasized the value of hard work and patience to succeed during the residents' graduation last December.

One of his passions was photography. He had a keen eye for taking pictures of people in action, picturesque sceneries and documenting events. He even proposed a post-graduate course on photography especially in selecting the proper angle, exposure and lighting before and after cosmetic surgery and showcased a photo exhibit of his works.

Diplomate exam on Sep 17, 2010. His extended stay was instrumental for our full accreditation and Dr. Pascual, his previous training officer and chair admired him for his extraordinary ideas and trusted him to accomplish certain tasks beyond his comfort zone.

He saw the potential of a good clinical practice in cosmetic surgery and pursued subspecialty training in facial aesthetic surgery under the Facial Aesthetic Core of ENT Surgeons (FACES) in 2010. Afterwards Jomar and his wife Amy established the Asian Aesthetic Center in Katipunan Ave. He became a visiting and subspecialty consultant in Maxillofacial, Facial Plastic and Reconstructive surgery of the department in 2011.

As a mentor, he unselfishly shared his skills and diligently assisted the residents during surgery working pro bono as a visiting consultant. He came early to attend grand rounds, was never satisfied with mediocre answers, persistently scrutinizing and demanding precision and accuracy. Sometimes his queries may have been perceived as nitpicking but they certainly echoed the effervescence and eagerness of a budding junior consultant plunging into the dynamics of clinical discussion. He helped organize the series of international postgraduate courses in Facial Plastic Surgery in QCGH from 2010 2012.

As a consultant, Jomar was a silent worker who actively participated and contributed voluntarily. He co-authored the paper on a case series of Tessier patients which is published in the current issue of this journal; he assisted in a case of tuberous sclerosis which he proposed as a case report to represent the department this year; he was preparing a
Jomar treated his patients with compassion and pampered them with care with his motto and familiar verse: Do all things with kindness. He was generous and gracious to hospital employees and treated the residents as members of an extended family. To break loose from the monotony and grime of daily routine, he would often invite residents to have dinner in their new house at LGV, share thoughts and perspectives about life over a bottle of beer or shots of tequila once in a while dishing out songs from his own repertoire. The staff will miss his silly grin while holding the microphone during videoke nights at the perennial watering hole in Bauschmann cafe. He had a toast for all occasions with a pocketful of cheers and stories to tell. One of his favorite lines was, for good looks and good life...

Jomar had a penchant for gadgets -- bought gifts especially for his wife, he savored food, dining and vacations with his family. As a husband, Amy could not ask for more. During the necrological rites, she confided that there were times when she would wake up and catch Jomar staring at her, giving her the impression that she was the most beautiful woman in this world. And to his two sons, Earl and Marcus, Jomar was a loving father who woke up early and took them to school, securing a brighter future for both of them.

True to his words, Jomar never slept and chased his dreams. He undoubtedly touched many people's lives along the way. The staff grieves and deeply mourns the passing of a fellow, colleague, comrade, mentor, brother and friend. His gestures and verses will continue to reverberate, long after he has gone. 